ISSN: 2581-8341

Volume 04 Issue 12 December 2021

DOI: 10.47191/ijcsrr/V4-i12-25, Impact Factor: 5.825

IJCSRR@ 2021

WwW.ijcsrr.org

\title{
In Depth Assessment on Digital Textile Printing Environment as the Concrete Path of Making Indonesia 4.0
}

\author{
Muhammad Faris Latief ${ }^{1}$, Adirizal Nizar ${ }^{2}$ \\ ${ }^{1,2}$ MBA Candidate, SBM ITB, Jakarta ${ }^{2}$ Lecturer of SBM ITB, Jakarta
}

\begin{abstract}
Textile-garment industry in Indonesia has been established as the primary industry and economy that becoming fundamental to nation's wealth. Well known as a top 5 of global market supplier, this industry predicted to keep score and improving their productivity to reach better position. In last 2019, Government of Indonesia already announced the roadmap plan of Indonesia 4.0, which put textile-garment industry as the one of priority industry that will be essentially adopting digital equipment and workflow to keep competitive and becoming the backbone of national industry alongside with other 4 industries mentioned. With this initiative being deployed and how the road map plan already announced, Author want to elaborate, assess and analyse how ready is digital adoption on textile-garment manufacturers, specifically on digital printing workflow. So on, this research will be titled "In Depth Assessment on Digital Textile Printing Environment as the Concrete Path of Making Indonesia 4.0". The main purpose of this research is to give the clear picture of how ready textile-garment industry Indonesia to fulfil both of extensive demand from domestic and global market by adopting digital equipment, in this research digital textile printing. By elaborating all the considerations and factor, we are hoping that there would be identified root issues beneath of this industry and directly formulating the best approach and solution for this industry.
\end{abstract}

KEYWORDS: Digital Textile Printer, DMAIC Six-Sigma, Industry 4.0, Indonesia Textile-Garment Industry, Lean Manufacturing.

\section{INTRODUCTION}

Industrial textile \& garment is one of the most priority businesses in Indonesia which giving more than 4 million jobs to Indonesians. This industry contributed 1.25\% of Q2 2021 total GDP growth which is almost seven percent during this pandemic. The strong exports also drive the industry rank and economy balance (INDONESIA-INVESTMENTS, 2021). As top $5^{\text {th }}$ world textile-garment supplier (GVR, 2021), Indonesia textile-garment industry is on the right path to keep improving as well as the stakeholders also putting more effort to keep competitive. By last 2018, Indonesian government has announced the roadmap plan of Indonesia 4.0 (KEMENTERIAN PERINDUSTRIAN REPUBLIK INDONESIA, 2018), an initiative plan to put the most priority industries, including textile-garment industry, as the backbone of nation wealth which expected to have digitalization approach for upcoming future. As priority industry, textile garment industry has been assigned to have more improvement from every segment from technical to non-technical, especially to adopt digital equipment and workflow.

In Indonesia, manufacturers are divided into two segmentations, which are upstream and downstream manufacturers. Upstream manufacturers are the factory that held the process of how textile/raw textile being created. It would use the raw materials that being composite with the fiber substrate and through the spin and woven process to become the roll-to-roll fabric based that ready for sewing or going for printing process in downstream process. In simple way, we can classify upstream manufacturing as the process to make only Textile or plain roll to roll fabric. While downstream manufacturers are the factory who's handled the process to evolve that kind of fabric or textile to become garment, clothing, and any end products that ready to be distributed to the retails and consumers. In this workflow we might see the treatment, dyeing and printing of fabric are the most crucial processes of workflows in downstream process. In Indonesia, there are at least roughly $+/-4000$ factories with at least 50-50 composition of downstream and upstream manufacturers (SASTRAATMAJA, 2021). Talking about digitalization using digital printer, we will leverage specifically on how downstream manufacturer managed to adopt digital printing equipment as the concrete path of making Indonesia 4.0.

This research already elaborating some of issues which beneath on this industry, especially during this pandemic situation:

1. During this pandemic, all manufacturers are struggling to have a normal production capacity and maintain the significant decreasing demand. 


\section{International Journal of Current Science Research and Review}

ISSN: 2581-8341

Volume 04 Issue 12 December 2021

DOI: 10.47191/ijcsrr/V4-i12-25, Impact Factor: 5.825

2. Less adoption of Digital industrial textile machine. From roughly 2000-2100 downstream manufacturers in Indonesia since last 4 years, the total installation of machine is only 50 units, it means the digital printing adoption for Industrial textile industry is about 2.4-2.5\% (IDC Asia/Pacific (Excluding Japan) IPDS, 2021)

3. Raw material shortage, and competition with imported garment.

4. Big gap between exporter countries. Looking on the current situation, China came as the number one textile exporter with more than $50 \%$ of market shares, while the second place, India, only supplies only less than $7 \%$ market shares of global textile. While Indonesia only managed to have $2.4 \%$ global market supply.

Revealing those main issues above, Authors want to explore on how far Indonesia digital adoption is and how Indonesia textilegarment industry can compete properly and reach top 3 world suppliers. There are research questions that being leverage which beneath of this research in general.

1. Is digital printing workflow necessary to be adopted by manufacturer in this near time, especially when we have pandemic situation?

2. How could manufacturers survive during this pandemic and ready to fulfil both domestic and global market demand?

3. How to gain the installation and population of digital printing textile in Indonesia to fulfil domestic market and close the gap with China market?

\section{REVIEW OF LITERATURE}

Authors are using DMAIC-Six Sigma as the main conceptual framework. DMAIC (define, measure, analyze, improve, and control) is an information quality improvement technique. The words in the abbreviation stand for the five stages of the procedure, as well as the tools needed to accomplish them. It is an important aspect of a Six Sigma project, but it may also be used as a hold process improvement technique or as part of other process improvement projects like lean. (Sarah E. Burke, 2017) DMAIC Process being leverages as the conceptual framework as this theory can determine the condition of textile-garment industry by putting down stepby-step to capture the best form of how the industry and main stakeholder such as manufacturers should behave and act.

Another was Lean manufacturing; Lean manufacturing relates to an emphasis on reducing as much waste as possible in logistics. During the leaning process, superfluous transfers, henceforth, and overstock in the distribution chain are all objectives for optimization. In this research, Authors are specific to adopt Toyota Lean Manufacturing which based on two Japanese cultural philosophies: waste reduction and respect for people (fulfilled the demand \& maintain their workers). An enhanced lean definition outlines seven forms of waste in the distribution chain that must be eliminated: (1) excess supply waste, (2) holding timesink, (3) transfer waste, (4) stock waste, (5) processing waste, (6) movement waste, and (7) output fault waste (F. Robert Jacobs, 2018).

\section{METHODOLOGY}

Authors are using the qualitative-in depth interview to capture deeper and specific insights from 5 manufacturers as tech buyers, 3 vendors as tech suppliers and 1 association. These respondents are representing the main stakeholders of textile-garment industry in Indonesia which. All the insights were based on open end questions and answer refer to their perspective. To get the valid answer, Authors also filtering the respondent designation as minimum national sales manager or product manager to capture the real insights and situation. All the insights then will be analyzed, summarized to get the silver lining on how the industry behave, act and plan in terms of digitalization of equipment, productivity and compete to fulfill both domestic and export market. The interview session will be directly captured as primary research findings via virtual meetings to avoid physical interactions during pandemic situation. The questionnaire will hold at least five major points:

1. Reason on why the respondent using or not using digital printing

2. Considerable factors before investing new machinery (Analog/Printing)

3. What kind of market/demand that linger to the current situation especially during pandemic situation?

4. Export market insights, chance, and competition

5. Assessment on digital printing readiness and the right timeframe to invest for new machinery especially digital printing 


\section{International Journal of Current Science Research and Review}

ISSN: 2581-8341

Volume 04 Issue 12 December 2021

DOI: 10.47191/ijesrr/V4-i12-25, Impact Factor: 5.825

\section{RESULT AND DISCUSSION}

Result are being extracted from the analysis and interview through stakeholders mentioned, and we've creating the silver lining amongst them.

\section{View from textile \& garment manufacturers (End Users)}

1. Not all manufacturers in Indonesia are mandatory to use digital printer: It always depends on the needs and capability of works from every manufacturer. As we know that upstream manufacturer doesn't need to invest through this digital printer as long as they have established upstream workflow to produce semi-final garment or plain fabric. Especially during this pandemic, lot of manufacturers all holding their spending to rejuvenate or doing the digital shifting.

2. Capacity of Productions to drive the cost: Quantity of daily basis for big manufacturers are remains from $50000100000 \mathrm{sqm} /$ day using analog-rotogravure, while digital printing is built to have an optimum cost of printing only below $50000 \mathrm{sqm} /$ day. For big manufacturers, they tend to keep using analog as it being used for long run production. So on, its all depends to manufacturer whether they want to explore new market using digital with short run approach or still comfort with existing long run business.

3. Trend of textile \& garment during pandemic: Manufacturers are agreed that we have discovered new application and trends of fashion during pandemic although the overall volume of production remains declining. Despite of declining trend volume, end users have discovered new opportunity during this hard time, such as Hazmat and APD (Clothes for health workers during pandemic), fabric mask, sports jersey (heavily for cycling jersey and gymnastic) and some order from SME's or brand owner who's doesn't have any machine to do in-house and looking to outsource their production with textile-garment manufacturers.

4. Export Market: the type of demand requirement might vary from long run to short run, from usual fashion to the haute couture, which is refer to the high fashion and limited supply. There are multiple demand from multinational brands such as Uniqlo, H\&M, Nike, Adidas, Zara and etc that being manufactured using both analog and digital equipment in Indonesia.

5. Quality of End Products: Quality of printing is debatable and being driven to several factors and variable. According to interviews, we are agreeing that Analog has the most consistent result of its products, but in regards, You need a good operator behind that. In other side, digital drive the more attractive result with detailed and pattern that Analog might really hard to get, but yes, its also depends on the operator, ink used, temperature and condition of machine itself. But all of respondents are agree that Analog has reliability and duty cycle that more than digital printing. That's why the analog printers can long last even more than 20 years of operations, while digital expected to have ages between 10-15 years.

From Manufacturers analysis, there are silver linings that can be remarks that all end users are aware and agree that digital printer adoption must be deployed to their sites. The time frame would be different as all end users have their own ability and financial plan especially during this pandemic. The necessity would be adjusted to every manufacturer, somehow, they only manage the bulk project and never touch the short run demand it's okay as all manufacturers have their own market segment to play, but it's always open to them to explore the new market and technology. All the decision and action also being driven from the owners and investors, including the equipment investment that categorized as an active asset. After summarized all the main consideration factors from technical to non-technical, digital shifting is not mandatory but it's necessary to keep the textile garment industry keep competitive, productive and more valuable specially to fulfil the global market demand (export market).

\section{View from vendors (digital machine, printers \& equipment suppliers)}

1. Pricing of Printers: It may vary but in general, for industrial textile machines with high speed and mass scale of production, it started from 1.5 billion up to 12 billion Rupiah at the highest. The differences can be seen from number and types of print heads, speeds, and manufacturer's principal. Commonly, Chinese brand is the cheapest, while Japanese and Italia are the more expensive. Every textile/garment factory can choose their own machinery based on production capacity that they have for sure

2. Market trends: The exposure of digital printing environment is on the good sights, as market tend to look for faster workflow, short run productions, vibes of pattern and SME's that wants to produce their own brand in creative and independent. This kind of trends could be bottlenecking as fast fashion trends which push every stakeholder to keep 
ISSN: 2581-8341

Volume 04 Issue 12 December 2021

DOI: 10.47191/ijesrr/V4-i12-25, Impact Factor: 5.825

producing the brand new and unique things, but still watching the environmental matters as one of the priorities. We believe that conventional old analog machine could generate larger carbon footprint comparing to digital printing technology. In Indonesia, this concerns might not be the headline, but we believe that in next 5 years, this is also becoming the considerable factors besides the revenue or fashion trends that dynamic in every timeframe.

3. What makes digital more suitable than analog in today's market: Fact that initial investment is even with analog, or even cheaper. A tremendous solution to capture today's market trend. Another is how return of investment can be reach in less than 5 years, and less supporting equipment to adopt, as pre-press/print activity using digital ecosystem would need a less process comparing to the conventional rotogravure. And we believe in the future, Industry 4.0 will be heavily adopted by Indonesia manufacturers, so on, digital printing is a concrete and first path to adopt the future ecosystem. To operate digital printing machine, we will give an intensive training for 2-3 months, then operator should be ready to run properly. Another, all vendors are responsibility to manage the after sales services from spare parts, consumables availability and 24/7 of technical support to keep the machine working optimum in end user's site.

4. Factors that drive manufacturer to invest through digital: Time would push manufacturer to invest. Somehow, the needs and market are the pull factor on manufacturer should invest on digital printing as soon as possible, but vendors also seeing how behaviour could be the biggest factor that drive the mind set to shifting into new technologies. Some of manufacturers already comfort with their own condition, but as pandemic hit, everybody needs to rejuvenate and looking into remarkable solutions of productions. The new generation that manages the factory also contribute on digital awareness.

5. Challenge that holds manufacturers to invest through digital: It's also the behaviour of already feeling well and comfort, or during this pandemic, manufacturers are late to shifting before then ended on they need to keep the labor or conventional orders and productions during limitation in pandemic situations. Invest through new equipment, including digital is not a one day of installation and then you can run the machine as soon as possible. It takes at least 3 months of preparations, from technical and non-technical which somehow, it can be counted as long from manufacturer's site. For mid manufacturers, no production up until 3 months would generate a new problem to their cashflow. That's why, only manufacturers that already established and existed that has capability to do this investment.

Looking on tech supplier's side, there are no issue on how machine can be ships or installed in manufacturer's side. Every vendor already has their own standard level of agreement and standard operational procedure to maintain the operations, imports, installation and after sales services to its customers. Installation process would take some months before the machine can properly running, including the quick training for new operators to manage the machine. There are other things that need to be consider. After sales services is the common issue as manufacturer might put the machine overworks or not properly during its daily operations. Vendors/dealers should be ready 24/7 if the machine is going into trouble, need some spareparts rejuvenation or even when the ink/consumable is running out. Vendors had to responsible with every industrial digital textile printer that they installed as the fully warranty and contractual services based on the agreement with manufacturers. Other vendors need to keep educate their market to adopt this new technology, because, although majority of the players in this industry already aware, there's no concrete movement as they tend to always "wait \& see" without proper research and development to explore about the new technology. Majority factory in Indonesia seems to be sluggish to adopt new technology as they have already comfort with things that they have now.

View from Association (Asosiasi Pertekstilan Indonesia)

1. Textile-Garment industry Indonesia from API's perspective: Currently, the awareness of manufacturers about digitalization of productions and operations showing a good trends, means that they have already known how vital is shifting into the new technology. It goes well on the upstream manufacturers, but maybe less adoption in downstream end users. But comparing to previous years, the growth would be significant if we look on how many digital industrial textiles printing has been installed. Must consider that pandemic bringing a massive challenge to all stakeholders as number of investment or installation on new digital machine would be postponed or even cancelled, as factory owners need to take care on their human power (labour) as Layoff is happening everywhere during this pandemic time as the implicated caused of lockdown, lack of textile-garment demand and shutdown activity of manufacture. So on, they need to tighten our belt, 


\section{International Journal of Current Science Research and Review}

ISSN: 2581-8341

Volume 04 Issue 12 December 2021

DOI: 10.47191/ijcsrr/V4-i12-25, Impact Factor: 5.825

hold the position and staying alive before looking into digital shifting. API expects that by 2022, activity and market should bounce back in better shapes as the pandemic handling is also controllable.

2. Population of digital printers in Indonesia: According to API's data, the population of digital printers industrial (roughly) per +/-2000 downstream manufacturers, is about 150-200 machines, it means that the percentage of machine in field comparing to its end users is below 10 percent.

3. Clustering of textile manufacturers in Indonesia: These are the area that currently becoming the hotspots of textilegarment business. All key cluster (Jabodetabek) and Bandung has print factory servicing them especially in Bandung (west Java) (larger garment manufacturers) has proportionally more print factory. While Semarang-Solo would be the big manufacturers textile-garment located in mid Java. Both are the fundamental area on textile garment industry, things to consider are accessibility, facility, and established industrial cluster that already existed. This clustering area of manufacturers can be seen as a logical phenomenon as every manufacturers would positioning or build their sites that near to the resources.

4. Policy and actions to grow the digital adoptions: There are some major points that API and Ministry of Industry Republic Indonesia being collaborated to push the digital adoption as the concrete path of industry 4.0 adoptions. First, API and all regulators are mandatory to generate the detailed roadmap plan that can be a legit guidance for all end users and suppliers in this textile-garment industry. Second, API would like to support all the incentive program which held by government to fasten the rejuvenation of equipments into digital machines as it reported (Katadata.co.id, 2021). Third, API with Ministry of Industry would determine the threshold of textile \& garment selling price to secure the domestic market and keep our products competitive in global demand. And fourth, API will be the centralized insights and information forum that can be accessed to everyone in this industry and giving the benefit back to society. And they believe that API in this period can be the catalyst to accelerate digital transformation in textile-garment industry Indonesia.

5. Forecast and outlook for industry in next 5-10 years: Expected that by 2030, populations of industrial digital textile printer is about $50 \%$ of total downstream manufacturer, it means that the machine in field is about 800-1000 units in next 10 years, and API is expecting that in 2035, majority of manufacturers already adapting fully digitalization ecosystem.

Association plays an important role as the medium to bridging government and manufacturers/end users. Association would be the frontliner on how industry condition could be seen in the surface. As every insight, information, membership and policy have been circulated in this stakeholder, association (API - Asosiasi Pertekstilan Indonesia) had responsibility to maintain the regulation and decision towards industry to keep representable and conducive. Collaborate with government, concrete incentive and catalyst are the actions that always being awaited by manufacturers. There are always dilemma and hard situation as stakeholders in this industry were not only manufacturers, vendors and government. There are another element such as Labor organization, investors, brand owners, outsourced partners etc. API with government (Ministry of Industry) needs to maintain this situation. Not all stakeholders will get what they want. Nobody will have win-win solution. But API should look into main vision on making Indonesia 4.0 in textile-garment industry as the concrete purpose to build a competitive industry not only for domestic market but also international market ahead.

Summarizing all the perspective from textile garment stakeholders, we've seeing various vantage points which determine the current condition of textile-garment industry in Indonesia. There are pros and cons of digital adoptions especially for digital printing in downstream manufacturing process which remarks as the concrete path to adopt industry 4.0. But have to consider, with less adoption of digital printer equipment in downstream manufacturers workflow, we're not able to compete even with India \& Pakistan that already advance in terms of digital textile garment adoption. Its still far away from closing the gap of production with China as long as our technology, behavior and regulations are not improving significant specially to adopt the new technology.

\section{CONCLUSION}

Less adoption on digital printing for downstream side can't be seen in just one or two perspectives, there are various variable that affects this less adoption, but yes, manufacturer is the key player who can drive themselves whether they can survive in this global and dynamic competition or not. Rest stakeholder might be the supporting and suppliers but not as primary as manufacturer's role. To capture the right conclusion, we would like to put forward the research questions and how this research could give the answer 


\section{International Journal of Current Science Research and Review}

ISSN: 2581-8341

Volume 04 Issue 12 December 2021

DOI: 10.47191/ijcsrr/V4-i12-25, Impact Factor: 5.825

IJCSRR@ 2021

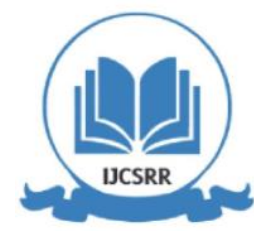

WWW.ijesrr.org

and explanation through them. To have better view of conclusion, Authors will explain based on the research questions that being mentioned in Introduction pages.

Question 1: Is digital printing workflow necessary to be adopted by manufacturer in this near time, especially when we have pandemic situation? From the research, leads, and potential market that manufacturer could expand, its necessary, but there is no pressure from the regulator to make it mandatory, as every manufacturer could determine and elaborate the best equipment that suits to their business. Somehow, manufacturers don't need any digital printer as they might focus to capture bulk-long run demand with no printed textile/garment. There would be a simple fashion or non-pattern/printed end products that currently they managed. But for export market especially when you are handling multinational corporation brands, it probably the based requirement to fulfil this order. So on, it's back to every manufacture whether its suitable or not, but according to this research and other study this technology will be the backbone of textile-garment productions in 2025 (Memon, 2017). From this explanation, researcher would classified this as an essential/necessary investment rather to become mandatory, and it will give a good precedence on industry 4.0 road map plan that being exhalated by government since 2019. If it's essential, the best momentum or time frame to do investment is as soon as possible. But we believe that majority of manufacturers are struggling on their cash flow and production due to the pandemic situation. Our suggestion, the investment can wait at least up until the rebound condition whether its on 2022 or upcoming years.

Question 2: How could manufacturers survive during this pandemic and ready to fulfil both domestic and global market demand? Based on the research, during this pandemic, manufacturers could remark to keep their cashflow healthy and surviving the current situation first. Internal organization needs to be maintained to "tightening the belt". Business development also needs to expand or look into another market by pivoting the business that they have. It doesn't have to be a new business but might be a new segment of market. As pandemic already hit the current and conventional demand/order, manufacturers should try to fulfil another market such as fabric mask, health worker's clothes (hazmat, scrubs etc.), pivoting into market that they haven't explore before. Short run demand is also something that worth to discover, as the quantity of demand would be small, but the customer is mushrooming. That's why when pandemic seems to be calmer, manufacturer should look for digital printer investment to capture alternative market that currently growing significant and valuable for global demand.

Question 3: How to gain the installation and population of digital printing textile in Indonesia to fulfil domestic market and close the gap with China market? So on, we are talking about "Digital Printing Go to Market" approach, what being considered and key points that we could address according to this research. Off course that manufacturers came as the biggest driver on how digital printer being absorbed, but we can't deny that active involvement from government, association, suppliers and customers will effects on how manufacturers invest on new digital machine. Harmonized and supporting environment between all stakeholders will generate a healthy competition and open all the opportunity of business. Government incentive will be the concrete catalyst as their funding, or discount on taxes through new equipment's investment will fasten the process of digitalization. Their policy and regulations on protecting local's manufacturers will also being appreciate but have to consider its not directly erasing the flexibility to import raw materials from other countries. Government should keep the balance of power to leverage this business keep appetite to all players. While association will play an essential role as the open forum and neutral medium for every stakeholder in this industry. Association should manage to give a guidance and support (non-material) to bring a good precedence on textile-garment industry in Indonesia. Association also responsible to manage their member, regularly listing their market sizing and giving much more information to manufacturers, buyers, and investors about conducive business climate in Indonesia. Association is a frontline of textile industry Indonesia, in this circumstance, API (Asosiasi Pertekstilan Indonesia). Another was from vendor/ machine suppliers. As there were lot of choices from various brands, competitive price, skilled technician and prime after sales services, there should be no worries for manufacturers to invest as there are available sources. The "digital go-to" market customer journey will elaborate implementation plan in specific way to capture how's the best practice from manufacturer's side to do digital transformation, in this situation, to buy the digital printing equipment.

\section{IMPLEMENTATION PLAN}

To implement more digital printing being absorb as the concrete path to leverage industry 4.0 in textile-garment industry of Indonesia, we need an outlook 1-2 years ahead. This implementation plan would elaborate the three stages of "digital go to market" customer journey. The focus will be on manufacturer's side as the main driver and subject of this industry 


\section{International Journal of Current Science Research and Review}

ISSN: 2581-8341

Volume 04 Issue 12 December 2021

DOI: 10.47191/ijesrr/V4-i12-25, Impact Factor: 5.825

IJCSRR @ 2021

WwW.ijcsrr.org

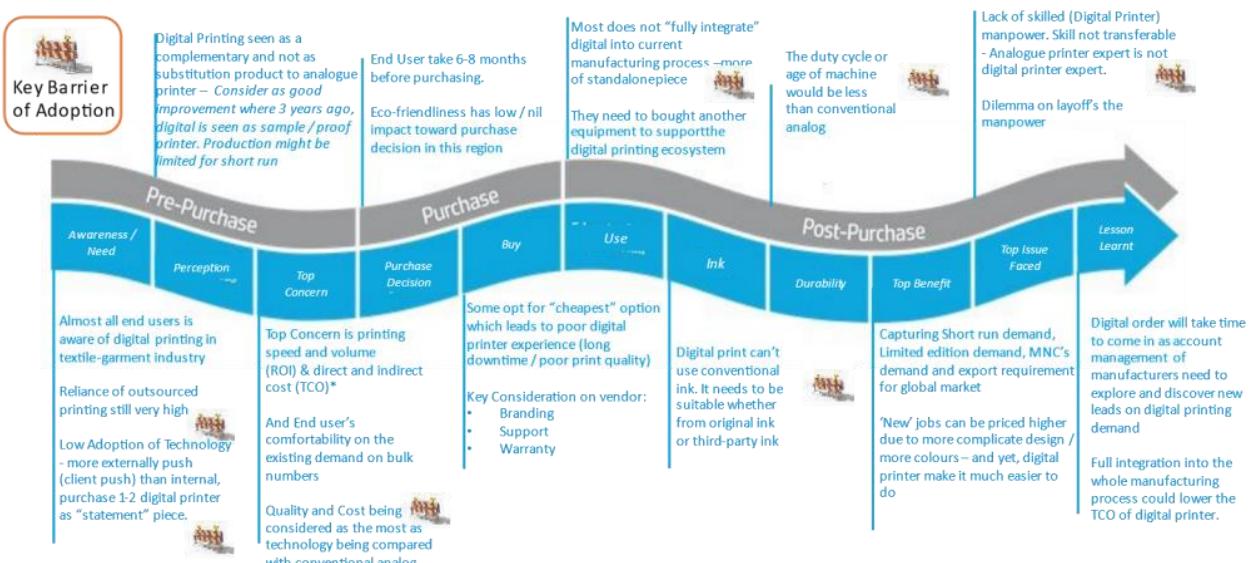

I. Figure Customer Journey: "Digital go-to Market"

Source: Author, 2021

From this flow, there are three main stages on how manufacturers absorb the digital equipment. There are Pre-purchase stage, Purchase stage and Post purchase stage.

1. Pre-Purchase Stage: This stage is referred to the initial view of manufacturers before they do investment. There are crucial considerations beneath this stage as they will calculate the TCO (Total Cost Operation) and ROI of the investment, then the quantity and quality that can be assured using this digital machine. manufacturer should look on future demand, because we're talking about global competition when the top three countries such as India, Pakistan and China already using digital textile printer as their main production line for export market. Must consider that manufacturers would have 6-8 months before they purchase some machine. If we have a strong source of information from association and agencies, rigid guidance and always given tax holiday by government, the preparation can be shortened for about 2-3 months, and the population of machine would be faster to reach expected numbers in terms of machine in field. So far, the pre-purchase stage also needs to be discussed with owners, procurements, and every internal stakeholder of manufacturers as this machine will be the main production line in upcoming future.

2. Purchase Stage: This is the stage that we're expecting being discovered or agreed by manufacturer. Buying a new equipment, Manufacturer will also look on how long the machine being installed, as this will leverage a gap time. This gap time can turn into a damage if the machine wasn't installed on time or having a significant issue which delay the production process and impacted to the cashflow.

3. Post Purchase: The last stage probably another crucial moment of manufacturer when they realized this new equipment is working out with the ecosystem they have or bringing unfortunate event. In the Top benefit of Post purchase, manufacturer could Capturing Short run demand, Limited edition demand, MNC's demand and export requirement for global market. New' jobs can be priced higher due to more complicate design / more colours - and yet, digital printer makes it much easier to do. Unfortunately, this purchase could bring some issue on Lack of skilled (Digital Printer) manpower. Skill not transferable - Analogue printer expert is not digital printer expert. Other is dilemma on layoff's the manpower because digital only need less human power to operate. In order/production demand, manufacturers should expand and prepare their business strategy to optimize this digital printer machine whether it goes for short run small medium enterprise demand or aiming big to capture licensed production for multinational brands for export market. It will also consume time to discover, whether trial and error from technical to non-technical.

\section{REFERENCES}

1. F. Robert Jacobs, R. B. (2018). The Toyota Production System. In R. B. F. Robert Jacobs, Operation and Supply Chain Management (pp. 352-354). New York: McGraw-Hill Education.

2. GVR, G. V. (2021, March 1). Textile Market Size, Share \& Trends Analysis Report By Raw Material (Wool, Chemical, Silk), By Product (Natural Fibers, Polyester), By Application (Household, Technical), By Region, And Segment Forecasts, 


\section{International Journal of Current Science Research and Review}

ISSN: 2581-8341

Volume 04 Issue 12 December 2021

DOI: 10.47191/ijesrr/V4-i12-25, Impact Factor: 5.825

IJCSRR@ 2021

WWw.ijcsrr.org

2021 - 2028. Retrieved from Textile Market Size, Share \& Trends Analysis Report By Raw Material (Wool, Chemical, Silk), By Product (Natural Fibers, Polyester), By Application (Household, Technical), By Region, And Segment Forecasts, 2021 - 2028: https://www.grandviewresearch.com/industry-analysis/textile-market

3. IDC Asia/Pacific (Excluding Japan) IPDS. (2021). Indonesia Hard Copy Pheriperal and Production Printer report Q2 2021. Jakarta: IDC.

4. Indonesia-Investments. (2021, May 11). Textile and Garment Industry of Indonesia; More than Just Clothes, but Challenges Persist. Retrieved from Indonesia-Investments: https://www.indonesia-investments.com/news/todaysheadlines/textile-andgarment-industry-of-indonesia-more-than-just-clothes-but-challenges-persist/item 9405

5. Ishaque, M. (2019). Indonesian Textile Industry. Textile Focus, 1-2.

6. Katadata.co.id. (2021). Pemerintah Bantu Restrukturisasi Mesin Untuk Pulihkan Industri Tekstil. Jakarta: katadata.co.id.

7. Kementerian Perindustrian Republik Indonesia. (2018). Indonesia's Fourth Industrial Revolution: Making Indonesia 4.0. Jakarta: Badan Penelitian dan Pengembangan Industri Kementerian Perindustrian Republik Indonesia.

8. Memon, P. D. (2017). Digital textile printing market growing rapidly in Pakistan. Karachi: Pakistan Textile Journal.

9. Sarah E. Burke, R. T. (2017). The Certified Quality Engineer Handbook, Fourth Edition. Milwaukee: ASQ.

10. Sastraatmaja, J. K. (2021, 11 5). Interview based on the industry 4.0 in textile garment manufacture. (M. Faris, Interviewer)

Cite this Article: Muhammad Faris Latief, Adirizal Nizar (2021). In Depth Assessment on Digital Textile Printing Environment as the Concrete Path of Making Indonesia 4.0. International Journal of Current Science Research and Review, 4(12), 18011808 